New Heating Laboratory at the Building Research Station

A NEW laboratory for research on the heating of buildings has been completed at the Building Research Station of the Department of Scientific and Industrial Research so that work can go on all the year round, instead of only in the winter. The laboratory was opened on July 22 by Sir Frank Smith, Secretary of the Department of Scientific and Industrial Research, on the occasion of the annual visit to the Building Research Station of the Institution of Heating and Ventilating Engineers, which is providing a sum of $\mathfrak{E} 1,500$ to enable the studies, at the Station, of heating problems to be speeded up and extended. The laboratory is one room within a larger room. The smaller room, which is $18 \mathrm{ft} . \times 12 \mathrm{ft}$., is the test-room which is to be heated in all the different possible ways. It has a ceiling which can be screwed up or down so that both low rooms and high rooms can be studied. The larger room in which the test-room is situated isolates it completely from outside weather effects. The various walls of this outer enclosure can each be refrigerated and their temperatures can be controlled to $0 \cdot 1^{\circ} \mathrm{F}$. Modern heating methods have been utilized in the control of the outer enclosure. Every surface is panel-heated or panel-cooled by brine which circulates in pipes in the walls, floor and ceiling. For cooling the brine which refrigerates the walls, a $4 \frac{1}{2}$-ton ammonia compressor is installed in the engine-room at one end of the laboratory. At the other end of the laboratory is an instrument room, where records are made of the conditions in the test-room and its enclosure. The new laboratory provides unique facilities for research and will undoubtedly mean a great speeding up of heating research.

\section{Research and Finance}

IN the leading article in Nature of July 11, there were, we regret to say, two inaccuracies which should be corrected. The system of grants in aid of the research associations and styled "the datum line system", described on p. 52, was superseded, some two years ago, by another system which, for the sake of brevity, may be called "the block grant system". The Department of Scientific and Industrial Research now makes an annual block grant to an association, provided that a definite sum is assured, in the form of subscriptions, by the industry concerned. The block grant and the industrial income have no rigid mathematical relationship; the ruling principle being that, added together, they must provide such a sum as will, in the opinion of the Advisory Council of the Department, form an adequate financial nucleus for a co-operative research organization for the industry in question. In order to encourage further expansion, the Department offers $£$ for $£$ on sums subscribed over and above the initial industrial income, up to a stated maximum, which, again, is fixed on the advice of the Advisory Council. This new system was the outcome of the big appeal made to industry a few years ago to play its part in expanding the operations of the research associations. The other inaccuracy was the paren. thetical statement, on p. 52, that the woollen industry raises its contributions to co-operative research by means of a statutory levy. It is a fact that for some years now the woollen industry has been conducting propaganda in favour of the institution of such a statutory compulsory levy, but no measure for the attainment of this object has yet been introduced into Parliament. On the other hand, it may be remembered that a Rubber Industry Bill, having for its object the institution of a statutory levy, was introduced into Parliament and finally dropped owing to the defection of a prominent firm in the industry.

\section{Chamberlain Memorial at the University of Birmingham}

IN connexion with the centenary celebrations of the birth of Joseph Chamberlain, the first Chancellor of the University of Birmingham, Sir William Waters Butler has given $£ 10,000$ to provide scholarships, to be known as the Joseph Chamberlain Memorial scholarships. The University has also received a generous benefaction from Sir Charles Hyde, Bart., who has offered $£ 10,000$ towards the museum of the new Medical School, with the suggestion that this part of the new building should be known as the Chamberlain Memorial Museum. It is felt that this gift, like that of Sir William Butler, is very appropriate to the occasion; for it is well known that the University, of which Mr. Chamberlain was the founder and first Chancellor, occupied a foremost place in his regard, as being an essential part of the city for which he had done so much. His fore. sight in placing the new buildings in Edgbaston, where there would be ample room for expansion, has been notably justified in the event. It may well be that the most enduring monument to his name will be the University of Birmingham. Mr. Chamberlain's interest in medical research was made evident in the part he took in the establishment of the London and Liverpool Schools of Tropical Medicine.

\section{Roman Sites and the National Trust}

A NEW museum of Roman antiquities from Hadrian's Wall at Housesteads Camp, north-west of Hexham, was opened on July 23 by Prof. G. M. Trevelyan, vice-chairman of the National Trust. The cost of the building has been defrayed out of funds which have accumulated as a result of the greatly increased number of visitors, who now go to inspect the camp. In 1935 they numbered no less than 15,000. Housesteads, or Borcovicus, which on its north side abuts on the Wall, covers an area of five acres. It is not only one of the finest sites on the wall, but it is also one of the most completely excavated Roman camps open to view in Great Britain. During the excavations, a number of important finds were made, and these, with other antiquities, will be housed in the new museum. The site of five acres, a milecastle and three quarters of a mile of the wall itself were presented to the National Trust in 1930 by the owner, Mr. J. H. Clayton, a well-known Northumbrian antiquary. The site is now under the 